\title{
Sciendo
}

DOI: $10.2478 /$ lpts-2019-0001

PHYSICAL AND TECHNICAL ENERGY PROBLEMS

\section{CATEGORISATION OF ANCILLARY SERVICES FOR PROVIDERS}

J. Ehnberg ${ }^{1 *}$, O. Lennerhag², E. Hillberg ${ }^{3}$, A. Perez ${ }^{4}$, A. Mutule ${ }^{5}$ I. Zikmanis ${ }^{6}$

${ }^{1}$ Chalmers University of Technology,

Electrical Engineering,

11 Hörsalsvägen, Göteborg, 417 56, SWEDEN

${ }^{2}$ Independent Insulation Group,

5 Storgatan, Ludvika, 771 30, SWEDEN

${ }^{3}$ RISE Research Institutes of Sweden,

4 Brinellvägen, Borås, 504 62, SWEDEN

${ }^{4} \mathrm{ABB}$,

12 Ludvikavägen, Ludvika, 771 31, SWEDEN

${ }^{5,6}$ Institute of Physical Energetics, 11 Krivu Str., Riga, LV-1006, LATVIA

*e-mail: jimmy.ehnberg@chalmers.se

The focus of the work presented here is to raise awareness of how ancillary services within the NordPool area could be of value in supporting the future grid, and who could be the provider of these services. The ancillary services considered here are not limited to the current market, but also services for future market solutions as well as services for fulfilment of grid codes. The goal is to promote the development of existing and novel solutions to increase the utilisation and thus the value of equipment within the power system. The paper includes a techno-economical categorisation of ancillary services, from a provider's perspective, presenting opportunities and competition. Furthermore, procurers of services could utilise this kind of categorisation to identify possible providers or partners. The analysis of the categorisation shows a broad range of possible providers for each service and a broad range of possible services from each provider.

Keywords: ancillary services, black start, congestion management, frequency support, islanding, power quality, provider, stability, system restoration, voltage support

\section{INTRODUCTION}

Ancillary services can be defined in many ways but are often considered as the services and functions necessary to support the secure and reliable operation of the 
power system. These services have varying technical specifications and regulatory frameworks across the world, mainly influenced by the individual deregulation processes that have taken place in different countries [1]. Ancillary services have traditionally been provided from the centralized electricity production side, but in the future, other sources, such as Distributed Energy Resources (DER) and loads, are expected to provide these services to ensure a sustainable and reliable power supply for all levels in the grid. Ancillary services are still commonly provided by generators but to some extent also by loads and other network devices [2].

The European Network of Transmission System Operators for Electricity (ENTSO-E) [3] defines ancillary services as:

"...the range of functions which TSOs contract so that they can guarantee system security. These include black start capability (the ability to restart a grid following a blackout); frequency response (to maintain system frequency with automatic and very fast responses); fast reserve (which can provide additional energy when needed); the provision of reactive power and various other services".

The Federal Energy Regulation Commission (FERC) [4] defines ancillary services as:

"the services necessary to support the transmission of electric power from seller to purchaser, given the obligations of control areas and transmitting utilities within those control areas, to maintain reliable operations of the interconnected transmission system. Ancillary services supplied with generation include load following, reactive power-voltage regulation, system protective services, loss compensation service, system control, load dispatch services, and energy imbalance services".

In [5], the Union of the Electricity Industry (EURELECTRIC) defines ancillary services as:

"all services required by the transmission or distribution system operator to enable them to maintain the integrity and stability of the transmission or distribution system as well as the power quality".

The definitions of ancillary services have some coherence but there are small differences which could make it hard to get an understanding of what they actually are and if you could provide this kind of services. The differences in categories could stem from independent market deregulation in different parts of the world, which do not follow a common approach, as well as there are differences in the power system structures and available resources [1]. This might be a specific problem for future providers that are today not active in the power area, which is a target group at least according to the FERC that specifically addresses load dispatch and energy imbalance services.

A power system that could meet the paradigm shift that is expected in the grid with a high level of intermittent renewable energy sources [6], [7], converter-based resources [6] and load is needed. However, this does not only create the paradigm shift and its challenges, they can also be part of the solution [6], [7]. The possibilities for a limited number of providers and battery system to mitigate frequency and voltage stability issues are discussed in [6]. A similar categorisation to the one provided in this paper is presented in [7] and is based on the time-scale of the different ancillary services. However, it has a focus on thermal power plants and storage technologies 
and the connection to specific present and future services is limited.

Storage technologies as providers of ancillary services are discussed in [8] and the paper shows which technology is suitable for which ancillary service. Another possible provider of ancillary services is a different type of load, often called demand response. A review of different types of demand response regimes is presented and the possibility to intervene with the grid is demonstrated in [9]. The review is based on different hieratical levels of power system studies (HL1 to HL3), which gives a good overview of the problem but has limitation to evaluate new opportunities to provide services.

There is an increased interest by new actors in the grid business; more people see and want to see more opportunities, for example, owners of distributed generation [10]-[12], battery system [11], [13] and loads, either individual or as virtual power plant (VPP) [10], [12], [14], [15]. The focus is mainly on participating in different types of the markets based on active power with a specific focus on energy and energy markets. However, there is also opportunity with more local focus by creating energy markets on distribution levels [12], [13]. Ideas of participation in frequency control and restoration also exist with well-developed bidding strategies [10] and evaluation of their economic benefits [11]. Creating VPP, by the use of, for example, aggregators, is one way to utilise also the benefits from small consumers, and opportunities are well identified at least for short-term electricity markets [14], [15]. More direct involvement is also proposed using intelligent loads (IL) [12]. By having this infrastructure in place, the step towards a more extensive participating of DG, VPP and IL into providing more ancillary services is not long. It is necessary to know more about the possibility.

The technical possibility to provide an ancillary service is today the only requirement to be a provider. Another crucial factor could be competitiveness with other providers, in terms of cost, but also with minimum impact on the environment and society. The economical evaluation can be based on an open market, which is already available for some of the services, but for many this is not the case. The other two dimensions of sustainability (i.e., environment and society) are more difficult to assess and, therefore, they are only generally addressed. In some cases, these dimensions are related to the economic area via, for example, diverse types of $\mathrm{CO}_{2}$ taxes.

The goal of the paper is to illustrate the existing and probable future ancillary services from a provider's perspective.

\section{GOAL OF THE PAPER}

The goal of the paper is to provide a tool in order to evaluate which ancillary services can be provided by whom, from a perspective of owners of different power equipment, the so-called providers.

First, providers can identify the services they can provide. To some extent, they could also identify which services are closer to implementation than others. This is of extra importance to involve relatively new and future actors to provide ancillary services (e.g., hydrogen producers). 
Second, a potential provider can see what kind of competitors they have for a certain service. This will not only determine the future price, but also which opportunities will appear at all. Since some services are more local than others, then the location of the competitors is also of importance.

Finally, the categorisation may be used to identify suppliers for someone that has the need for a certain service, e.g., fulfilment of grid codes, like reactive power compensation and harmonics mitigation, or for internal processes. This could lead to large benefits since the internal costs could be compared with the costs from an external supplier.

A larger range of providers of ancillary services could also have great environmental benefits because less equipment in general is needed. Less equipment means less material and, therefore, both environmental and economic dimensions are beneficial.

The procedure of evaluating different perspectives is out of the scope of this paper but a standard method can be expected to be used, perhaps depending on local and political circumstances.

The paper focuses on the NordPool area because markets of the ancillary services are by nature restricted to only one area. It also reduces the complexity to describe different services.

However, despite the focus in this study the categorisation can easily be translated to all other areas with some minor updates. Mainly updates on the ancillary services are needed to meet the local requirements. However, a review of the mapping might also be needed to make sure it matches the service.

\section{ANCILLARY SERVICES}

There is some ambiguity when finding a common categorisation for ancillary services, which can lead to confusion. According to [2], ancillary services have evolved to include new types of ancillary services, for instance, those that can be provided by renewable sources such as wind and solar power. Furthermore, the terminology used follows closely the terminology given by the ENTSO-E network codes. The authors found that three main groups of ancillary services could be pointed out, these being ancillary services related to: (1) frequency control, (2) voltage control, and (3) system restoration.

Report [2] also mentions an emerging ancillary service associated with renewable energy sources, more specifically wind power. This type of ancillary service would be focused on providing back-up and other services to the system operators, to counteract the stochastic behaviour of the wind power generators.

Therefore, the services are divided into four categories: frequency support, voltage support, system restoration and other services. Each service is described shortly, mainly based on the provider of today. The market for each service, if such exists, is described based on at least an existing market structure to exemplify. If no market is known, a common method to provide the service is described and market structure is proposed. If the service is dependent on localization of the provider, it is marked with an $\mathrm{L}$ in the overview table on the mapping. 


\subsection{Services Related to Frequency Support}

\subsubsection{Overview}

Frequency in power systems is a system indicator of the balance between generation and consumption of electricity. Furthermore, frequency is tightly coupled to the active power in such a way that an excess in the active power input results in an increase in frequency, and vice versa. Loads and equipment such as induction motors and transformers are sensitive to frequency changes. For instance, frequency drops are known to cause high magnetizing currents in devices [16]. However, the indirect consequences may be much larger and even a threat to the operation. In classical power systems, the frequency is sustained by means of control systems through the governor of synchronous generators in the same synchronous area. However, with the phase-out of some conventional generation resources, enforced by market liberalization and/or environmental concerns, the share of non-synchronous converter-based generation has increased considerably.

\subsubsection{Frequency Containment Reserve (FCR)}

The purpose of the FCR is to stabilize the system frequency. In the NordPool countries, the FCR has been split into FCR-N for normal operation $(50 \mathrm{~Hz} \pm 100 \mathrm{mHz})$, and FCR-D for disturbance operation $(49.9-49.5 \mathrm{~Hz})$ [17]. The FCR control tasks are commonly referred to as primary frequency control.

FCR takes place as a joint action of the participating generating units within the synchronous area. It is provided through the turbine governors, with local and decentralized control, giving a fast and automatic response. According to [8], FCR should follow two main principles: (1) bring the rate of change of the frequency deviation to zero, and (2) the FCR available capacity shall be fully activated at the maximum steady-state frequency deviation.

Generally, the full activation time of FCR-D is between 0 and 30 seconds, sustaining up to 15 minutes, after which it is released [2]. According to the survey presented in [1], the deployment start of the FCR is instantaneous, and it is fully committed in less than 30 seconds in most EU countries. In the NordPool area, $50 \%$ of FCR-D shall be active within 5 seconds, and it shall deliver its full response within 30 seconds [18]. On the other hand, since FCR-N is within normal operation mode, its activation is slower compared to the FCR-D, i.e., FCRN is activated within two to three minutes [18].

The providers of FCR are today generators equipped with a speed governor. The demand side also participates in this control due to the self-regulation of frequency dependent loads such as directly connected induction motors and loads equipped with under frequency relays; however, loads are rarely considered as part of the frequency regulation [1]. In the NordPool area, automatic load shedding is not part of the FCR, but instead considered as system protection for disturbances where the FCR-D has been unsuccessful to prevent the frequency to drop below $49.5 \mathrm{~Hz}$ [19]. 
In addition, it is technically possible to provide FCR by HVDC connections between neighbouring synchronous systems. Such frequency-controlled regulation of HVDC may be referred to as emergency power and is in the NordPool area [17] considered partly within the FCR-D and partly as system protection to mitigate disturbances below $49.5 \mathrm{~Hz}$ [19].

\section{Market Related Aspects}

FCR is a market product procured by the TSO. There are several procurement methods in electricity markets, including compulsory provision, bilateral contracts, tendering process, and spot market. In the NordPool area, the FCR (FCR-N and FCR-D) is obtained through a tendering process [20]. The generation companies can submit their FCR-N/D bids one or two days ahead the operational day. The bids can be longer than one hour, but still limited to a number of consecutive hours, for instance, six hours for the bids submitted two days before, and three hours for the day ahead bids [21].

The payment method can be regulated price, pay as bid resulting from a tendering process, common clearing price resulting from a spot market, or nonremunerated. In the NordPool area, the remuneration method is pay as bid. In most cases, the TSOs pay for the product availability, but in some cases, a frequency utilization payment is also added [20].

\subsubsection{Frequency Restoration Reserve (FRR)}

The FRR process aims at restoring the frequency back to its nominal value by activating the reserves within a predefined time [22], by modifying the set point of reserve-providing units [2]. FRR also aims at replacing the FCR reserves. The control tasks related to FRR are commonly referred to as secondary frequency control.

The activation process can be either automatic (aFRR, delivered from spinning reserve) or manual (mFRR, delivered from spinning and standing reserve). FRRs are managed by the TSO [2].

A synchronous area may contain several load-frequency control areas (LFC area), e.g., delimited by countries. In such cases, the Area Control Error (ACE), which is defined as the difference between the scheduled and actual power flows for an area, helps determine the participation factor of that area in the frequency restoration process [22]. As mentioned in [1], every area is responsible for maintaining its load and generation. This means that the flows in and out the area should be restored by FRR, bringing the ACE to zero.

Only generating units located in the same LFC area from where the imbalance originates should participate in this control (normally it is the responsibility of each LFC area to keep its load and generation in balance) to avoid unplanned power flows. Loads do not participate in this control [1]. 
The most common procurement methods for FRR are bilateral contracts, tendering processes, and spot market. Reported payment methods are pay as bid and common clearing price. Furthermore, the remuneration structure is based on availability and utilization, as it is inherent from the previously mentioned procurement methods [20].

\subsubsection{Replacement Reserve (RR)}

Replacement reserves (RR) are defined in [23] as follows:

"the active power reserves available to restore or support the required level of FRR to be prepared for additional system imbalances, including operating reserves".

The RR replaces utilized FRR-reserves, helps manage congestions in the transmission network, and brings the frequency and the interchanges back to their target values when FRRs are unable to perform this task [1]. RRs are activated manually and centrally at the TSO control centre [2], i.e., through manual changes in the dispatching and commitment of generating units.

The service deployment time varies widely among TSOs. Non-synchronous resources are treated differently in this service [1]. According to the CIGRE global survey presented in [24], the RR ("Tertiary Control Tasks") timeframe is generally 30 to 120 minutes.

\section{Market Related Aspects}

Some aspects of RR are related to trading for energy balancing purposes, which is not a service provided by the system users to the TSO and hence not an ancillary service, i.e., balancing takes place among the system users in the electricity market that aims "to balance their financial positions" [20].

The remuneration structure of this ancillary service is pay as bid in most systems [20]. Availability and utilization payments are the most common remuneration structures. In some markets, fixed and utilization frequency payments exist, for instance, in Great Britain. Opportunity cost payments are rarely seen, since these are hard to compute [20].

\subsubsection{Fast Frequency Response (FFR)}

FFR can be achieved by rapid injection of active power or reduction of load, in a timeframe so that it can arrest a frequency decay, i.e., decreasing the Rate of Change of Frequency and the nadir, giving sufficient time to activate the FCR [25]. FFR has been proposed to be available within 2 seconds and sustained for at least 15 seconds [26].

Possible providers of FFR are conventional generators, loads with under frequency relays, synchronous storage units like pumped hydro, HVDC interconnectors 
to other power systems, doubly-fed induction generators (DFIG) and full converterbased wind turbines [2], as well as energy storage systems (ESS) [18].

FFR can be in the form of real inertia from rotating mass or emulated by power electronics-interfaced power sources. Moreover, the emulated response is commonly referred to as synthetic inertia.

\section{Market Related Aspects}

Currently, FFR does not exist as a product on the electricity market. Some system operators have proposed the introduction of this ancillary service in their system, for instance, in the Electric Reliability Council of Texas (ERCOT) power system. According to ERCOT's concept paper on future ancillary services [25], the market considerations of a suggested Synthetic Inertia/FFR ancillary service can be summarised as follows: First, the required amount of inertia is determined, which later would be acquired through a Residual (alt. Reliability) Unit Commitment (RUC) process. Normally, the RUC process precedes the Day Ahead Market (DAM), and during the RUC process the day ahead schedule resulting from the DAM remains locked, i.e., the units committed in the DAM are considered as "must run" during the RUC process [27]. Provision of FFR ancillary service under the aforementioned structure implies that resources aiming at provision of FFR/Synthetic Inertia would necessarily have to participate in the DAM. Moreover, the total amount of RUC awarded in the system is normally limited by the total energy bid minus the day ahead scheduled energy plus the upward ancillary services (resulting from the DAM) [27].

\subsection{Services Related to Voltage Support}

\subsubsection{Overview}

For electrical equipment to function properly, the supply voltage must be within certain required values; hence, actions should be taken to fulfil this requirement. While frequency is a system wide parameter, voltage is a local quantity tightly coupled to the reactive power injection to network nodes [2] and thereby a more local parameter. The measures can be performed in steady state or in dynamic operation mode [2].

\subsubsection{Normal Operation: Power Factor-, Reactive Power-and/or Voltage-Control}

The aim of this ancillary service is to control the voltage level of the network nodes. This is achieved by injecting or absorbing reactive power at the voltage controlled node, so that the voltage is kept within acceptable margins. In general, the technical requirements of this service are principally concerned with the absorption and production of reactive power, expressed in fractions of the nominal active power at the point of delivery [1]. The timeframe of operation is within hours [2], with immediate deployment time, and continuous operation to keep the voltage at its nominal and ensure stability [1]. 
Providers of this service are, e.g., synchronous sources, static compensation, SVCs, tap changing transformers, transmission lines (by switching), virtual power plants, demand facilities, and load shedding [2]. Devices interfaced to the grid through power electronic converters, such as wind turbines, PV, and HVDC-VSC links, can also provide this service.

\section{Market Related Aspects}

Provision of this service is compulsory and regulated in the grid codes. The services are non-remunerated in most systems, but bilateral contracts and tendering process have been reported in some countries, with regulated and pay as bid payments [20]. When present, the remuneration method is fixed or for availability. Due to the local nature of voltage, this ancillary service is prone to the exercise of market power [20].

\subsubsection{Fast Reactive Current Injection}

Fast reactive current injection can be defined as the capability of a generator to provide a proportionate response to a voltage dip [2]. Some possible specifications for this ancillary service could impose requirements on the delivered response, e.g., rise time, overshoot, and settling time [26].

It aims at controlling the voltage in a dynamic timeframe from tens of milliseconds to minutes, enhancing the dynamic security of the system, e.g., in order to prevent voltage collapse, or to limit it to some extent. It also helps with other voltage quality issues [2].

The providers of this service could be synchronous generators [26], reactors and capacitors, SVCs, VSC-HVDC substations, FACTS devices [2] and other converter-based providers such as wind power plants, PV systems, and energy storage systems (e.g., batteries).

\section{Market Related Aspects}

Currently, there is no market structure in place for fast reactive current injection, but it is demanded in some grid codes. A suggestion given in [20] is that there should be a change in the mind-set regarding how this kind of service should be remunerated to reduce the system cost. This could be done by allowing the local provider with the lowest cost to provide the service.

\subsection{Services Related to System Restoration}

\subsubsection{Black Start}

Black start is defined as the set of actions aimed at bringing the system back to normal operation after disturbance that caused a blackout or state of emergency. 
It is carried out sequentially: 1) re-energization, 2) frequency management, and 3) re-synchronization [2].

Providers of this service are normally neighbouring TSOs by means of tie lines, and alternatively internal resources having black start capabilities, i.e., resources capable of controlling voltage and speed/frequency in a stable islanded mode [2].

\section{Market Related Aspects}

In the NordPool system, the capacity is directly procured based on system needs of the TSO.

\subsubsection{Islanding}

The requirements for islanding are similar to those of Black Start but the duration is longer. Maintaining generation-demand balance is the first-hand requirement for stable islanding operation. The generators in the island must be able to maintain the voltage and frequency. In addition, the generators should be able to keep the network impedance within range, the phase symmetry, the ability to handle fault currents, and the resynchronization with the rest of the network [2].

In a sense, all power systems are islanded. However, this does not mean that every generator can provide stable islanded operation by itself. One example is intermittent sources such as PV, which may very well function in a smaller islanded system, but they need additional generating sources or storage, e.g., during nighttime to provide a stable islanding operation.

\section{Market Related Aspects}

Currently, there is no market structure in place but the capability is regulated in some grid codes. The service is little more complicated since it can be hard to predict in what ways the system will split. A more dynamic market is proposed, since islanding occurs relatively seldom, and the market needs to be based on available resources rather than special installations. A fix feed-in tariff and thereby fix cost could also be a market solution to get a predictable system in an emergency situation.

\subsection{Other Services}

\subsubsection{System Stability Services}

One type of system stability service is Power Oscillation Damping (POD). The basic principle of POD is that active or reactive power is used to counteract oscillatory behaviour in the system.

Current providers of this service are, e.g., synchronous generators equipped with a Power System Stabilizer (PSS), STATCOMs, VSC-HVDC stations, and other FACTS devices. Some possible future providers of stability services are wind farms connected to the transmission network [28]. 
Some TSOs have established (or may establish in the future) in their grid codes that non-synchronous generation, such as wind farms, should provide frequency and reactive power regulation ancillary services. Furthermore, capabilities for the damping of power system oscillations may also be required [28]. Remuneration could be based on what extra cost can be added for removing this kind of requirement in the grid codes.

\subsubsection{Power Flow/Congestion Management}

Power flow management is basically a network planning related issue. This service also includes peak shaving/energy arbitrage, demand side flexibility, and load management.

Some possible providers of a power flow/congestion management ancillary service are, e.g., phase shifting transformers, on-load tap changers at substations, supplementary line regulators on feeders, switched capacitor banks at low voltage/ medium voltage substations, and coordinated reactive power injection of DG connected at the DSO level. The opportunities might increase for DG in the future due to a higher collective availability [2].

Providers of peak shaving/energy arbitrage could be, e.g., Battery Energy Storage Systems (BESS). The peak shaving and energy arbitrage capabilities offered by BESS have been demonstrated, e.g., in [29]. However, the companion paper [30] showed that the analysed BESS were not economically feasible without subsidy capital at the current battery prices (year 2016).

Providers of demand side flexibility could be industrial, residential and commercial loads. Demand side flexibility of commercial buildings based on the coupling of the inherent thermal energy storage characteristics of the building to the grid, by means of the heating-ventilation-and-air-conditioning systems, has been studied in [31]. The services provided by buildings include scheduling of pricesensitive load and load shifting (basically energy arbitrage).

\section{Market Related Aspects}

At the TSO level, there is the market dealt with in the energy market by, e.g., counter purchases. However, no such markets exist at the DSO level. Energy market at the distribution level can be implemented, access to smart meter data could be a key factor. The focus should be placed on adapting loads rather than production; virtual power plants could be used to implement the system by the use of aggregators.

\subsubsection{Power Quality Services}

Power quality services could include, e.g., harmonic mitigation. The basic principle of harmonic mitigation is that a harmonic component is imposed on the 
delivered current, e.g., in order to counteract an existing distortion in the grid. It could also be provided as coordination between, e.g., several wind turbines, where the phase angle is adjusted to minimise the harmonic current for each harmonic order, thereby limiting the total harmonic distortion at the point of connection [32].

\section{Market Related Aspects}

Currently, there is no market structure in place, but most grid codes include requirements on the harmonic emissions at the point of connection. A market based on fulfilling other grid codes is possible, but it requires the DSO to have a more open view on where in the grid the codes need to be fulfilled.

\section{PROVIDERS OF ANCILLARY SERVICES}

A mapping of ancillary services has been done from the perspective of which services a certain type of providers may contribute. The mapping also includes the colour coding used for this techno-economic consideration as can be seen in Table 1.

The Techno-Economic Categorisation of Ancillary Services Using the Following Colour Code

\begin{tabular}{|l|c|}
\hline Currently utilised, technically and commercially feasible & G \\
\hline Technically possible with minor modifications; & Y \\
Assumed smaller investments and/or close to commercially feasible & \\
(with respect to its present commercial setup and operation) & \\
\hline $\begin{array}{l}\text { Technically possible with major modification; } \\
\text { Assumed larger investments and/or distant to commercially feasible } \\
\text { (with respect to its present commercial setup and operation) }\end{array}$ & $\mathrm{R}$ \\
\hline Technically not applicable/possible and/or assumed economically infeasible & N/A \\
\hline
\end{tabular}

In Table 2, the mapping of ancillary services is presented for a list of different types of providers. This table also includes information regarding the importance of location of the provider of ancillary services.

The used numeral interpretation list for Table 2:

1. This is provided naturally through the inertial response of the generator.

2. While it is not used in Sweden, nuclear power is used in, e.g., France for freq. support.

3. This is part of the regulations for production units, it is not monetized.

4. This is normally only possible for down-regulation or if it is normally not producing the maximum available output.

5. In many cases, this is dependent on the converter rating. If the converter is not rated for higher capacity needed for continuous reactive support, this will not be possible during full production.

6. It may be possible for an arc furnace to contribute to lower flicker levels based on adjustments of the process.

7. More complex to realize since aggregator might be needed. 
Technical and Economical Categorisation of Ancillary Services from Different Types of Providers

\begin{tabular}{|c|c|c|c|c|c|c|c|c|c|c|c|}
\hline & FFR & FCR & $\begin{array}{l}\text { aFRR, } \\
\text { mFRR }\end{array}$ & RR & $\begin{array}{l}\text { Fast } \\
\text { reactive } \\
\text { current } \\
\text { injection } \\
\text { (L) }\end{array}$ & $\begin{array}{l}\text { Slow } \\
\text { PF, U,Q } \\
\text { control } \\
\text { (L) }\end{array}$ & $\begin{array}{l}\text { Black } \\
\text { start } \\
\text { (L) }\end{array}$ & $\begin{array}{l}\text { Island- } \\
\text { ing (L) }\end{array}$ & $\begin{array}{l}\text { System } \\
\text { stability } \\
\text { services } \\
\text { (L) }\end{array}$ & $\begin{array}{l}\text { Conges- } \\
\text { tion } \\
\text { manage- } \\
\text { ment } \\
(\mathrm{L})\end{array}$ & $\begin{array}{l}\text { Other } \\
\text { PQ } \\
\text { services } \\
\text { (L) }\end{array}$ \\
\hline $\begin{array}{l}\text { Hydro power } \\
\text { (run of river) }\end{array}$ & $\mathrm{G}, 1)$ & N/A & N/A & N/A & $\mathrm{Y}$ & $\mathrm{Y}$ & G & G & G & G & $\mathrm{R}$ \\
\hline $\begin{array}{l}\text { Hydro power } \\
\text { (w. reservoir) }\end{array}$ & $\mathrm{G}, 1)$ & G & G & $\mathrm{G}$ & $\mathrm{Y}$ & $\mathrm{G}, 3)$ & G & G & G & G & $\mathrm{R}$ \\
\hline Nuclear & $\mathrm{G}, 1)$ & $\mathrm{Y}, 2)$ & $\mathrm{Y}, 2)$ & G & Y & $\mathrm{G}, 3)$ & N/A & N/A & G & G & $\mathrm{R}$ \\
\hline Gas/oil & $\mathrm{G}, 1)$ & $\mathrm{G}$ & G & $\mathrm{G}$ & $\mathrm{Y}$ & $\mathrm{G}, 3)$ & G & G & $\mathrm{G}$ & $\mathrm{G}$ & $\mathrm{R}$ \\
\hline Waste & $\mathrm{G}, 1)$ & G & G & $\mathrm{G}$ & $\mathrm{Y}$ & $\mathrm{G}, 3)$ & G & G & G & G & $\mathrm{R}$ \\
\hline Biomass & $\mathrm{G}, 1)$ & $\mathrm{G}$ & $\mathrm{G}$ & $\mathrm{G}$ & $\mathrm{Y}$ & $\mathrm{G}, 3)$ & G & G & G & $\mathrm{G}$ & $\mathrm{R}$ \\
\hline $\begin{array}{l}\text { Classic } \\
\text { HVDC }\end{array}$ & $\mathrm{Y}$ & G & $\mathrm{Y}$ & $\mathrm{Y}$ & N/A & Y & $\mathrm{R}$ & $\mathrm{R}$ & $\mathrm{R}$ & G & $\mathrm{R}$ \\
\hline HVDC-VSC & $\mathrm{Y}$ & G & $\mathrm{Y}$ & $\mathrm{Y}$ & G & $\mathrm{Y}$ & G & G & G & G & $\mathrm{Y}$ \\
\hline PV & $\mathrm{Y}, 4)$ & $\mathrm{R}$ & $\mathrm{R}$ & $\mathrm{R}$ & $\mathrm{R}$ & $\mathrm{Y}$ & $\mathrm{R}$ & $\mathrm{R}$ & $\mathrm{Y}$ & $\mathrm{G}$ & $\mathrm{Y}$ \\
\hline Wind & $\mathrm{Y}, 4)$ & $\mathrm{R}$ & $\mathrm{R}$ & $\mathrm{R}$ & G & $\mathrm{Y}, 5)$ & $\mathrm{R}$ & $\mathrm{R}$ & $\mathrm{Y}$ & G & $\mathrm{Y}$ \\
\hline Wave tidal & $\mathrm{Y}, 4)$ & $\mathrm{R}$ & $\mathrm{R}$ & $\mathrm{R}$ & $\mathrm{G}$ & $\mathrm{Y}, 5)$ & $\mathrm{R}$ & $\mathrm{R}$ & $\mathrm{Y}$ & G & $\mathrm{Y}$ \\
\hline $\begin{array}{l}\text { Pumped } \\
\text { hydro }\end{array}$ & G & G & $\mathrm{G}$ & $\mathrm{G}$ & G & G & $\mathrm{G}$ & G & $\mathrm{Y}$ & G & $\mathrm{R}$ \\
\hline CAES & G & $\mathrm{G}$ & $\mathrm{G}$ & $\mathrm{G}$ & $\mathrm{Y}$ & $\mathrm{Y}$ & G & $\mathrm{G}$ & $\mathrm{Y}$ & G & $\mathrm{R}$ \\
\hline $\mathrm{H}_{2}$ storage & G & $\mathrm{G}$ & $\mathrm{G}$ & $\mathrm{G}$ & $\mathrm{Y}$ & $\mathrm{Y}$ & G & G & $\mathrm{Y}$ & G & G \\
\hline BESS & G & G & G & G & $\mathrm{Y}$ & $\mathrm{Y}$ & G & G & $\mathrm{Y}$ & G & G \\
\hline Flywheel & G & N/A & N/A & N/A & $\mathrm{Y}$ & $\mathrm{R}$ & $\mathrm{R}$ & $\mathrm{R}$ & $\mathrm{Y}$ & G & $\mathrm{R}$ \\
\hline Thermal & $\mathrm{G}$ & $\mathrm{G}$ & G & $\mathrm{G}$ & $\mathrm{Y}$ & G & $\mathrm{Y}$ & $\mathrm{Y}$ & $\mathrm{Y}$ & $\mathrm{G}$ & G \\
\hline $\begin{array}{l}\text { Super- } \\
\text { capacitors }\end{array}$ & G & N/A & N/A & N/A & Y & $\mathrm{R}$ & $\mathrm{R}$ & $\mathrm{R}$ & Y & G & $\mathrm{R}$ \\
\hline Industry & $\mathrm{G}, 1)$ & $\mathrm{Y}$ & $\mathrm{Y}$ & $\mathrm{Y}$ & $\mathrm{R}$ & $\mathrm{R}$ & N/A & $\mathrm{Y}$ & $\mathrm{Y}$ & $\mathrm{Y}$ & $\mathrm{R}, 6)$ \\
\hline $\begin{array}{l}\text { Commercial } \\
\text { buildings }\end{array}$ & $\mathrm{Y}, 7)$ & $\mathrm{Y}, 7)$ & $\mathrm{Y}, 7)$ & $\mathrm{Y}, 7)$ & $\mathrm{R}, 7)$ & $\mathrm{R}, 7)$ & N/A & $\mathrm{Y}, 7)$ & $\mathrm{Y}, 7)$ & $\mathrm{Y}, 7)$ & $\mathrm{R}, 7)$ \\
\hline Household & $\mathrm{Y}, 7)$ & $\mathrm{Y}, 7)$ & $\mathrm{Y}, 7)$ & $\mathrm{Y}, 7)$ & $\mathrm{R}, 7)$ & $\mathrm{R}, 7)$ & N/A & $\mathrm{Y}, 7)$ & $\mathrm{Y}, 7)$ & $\mathrm{Y}, 7)$ & $\mathrm{R}, 7$ ) \\
\hline
\end{tabular}

(L) represents the importance of localization of the provider of the ancillary service (for other services, the provider is only required to be located in the same synchronous system unless transmission between the system is possible, then the scope is even broader). The letters in the cells are only an indication of the colour.

In Table 2, presumed providers can easily see what kind of ancillary services they have the possibility to provide by examining the row they are in. Based on information in the table, the provider will need to conduct more thorough investigation on the supply of a specific service due to local circumstances, such as grid limitation or other operating conditions. The table just provides a guidance on where to start developing business.

In columns for each service the competition between services can be examined. This information can be used to evaluate the value of participation.

Fast frequency response can be provided by a wide range of providers. However, some of them will require software updates. Very little loss of electricity 
production or additional losses are expected, which makes several of them possible and suitable providers. The relative need in the system is not expected to increase in the future but the capacity of some of the current providers is expected to decrease, which will create an additional need.

For the other frequency response services such as FCR, aFRR, mFRR and replacement reserves, the situation is quite similar and can be provided by many more providers than today. Some of the providers might require some control system updates and write the business contracts to the able to participate in the existing market(s). Renewable electricity technologies can provide the services, but they cannot up-regulate without losing production and their often intermittent behavior makes them sometime not available, not even for the down-regulating. The relative need of the system is not expected to increase, or maybe even decrease due to the trend of more and smaller production units. However, capacity of providers of today are expected to decrease more and faster than the need and will therefore create an additional need.

Reactive power/voltage and power factor control both fast and slow can also be provided by many providers but many of them will require some control system updates especially for the fast control. The production or consumption is dependent of the nominal power rating rather than active power provided, which gives opportunities. Therefore, there might be a need to increase the rating of generators or converters, depending on the type of provider, to avoid loss of any electricity production. The relative need of the service will probably not increase except in the distribution system where it probably will increase, due to a more complicated electricity consumption and production pattern in the future. Some of the large providers of today might not be available and, therefore, it can be concluded that more capacity is going to be needed in the future.

More providers of black start capability and islanding are available today. More providers of these services will increase the possibility of operation during outages or increase the speed for rebuilding the power system after extensive outages, which could have a major positive impact on the society as a whole. Especially islanding would provide the possibility to increase the production over time since less stops will be required due to grid problems. Black start and islanding are services that seldom if ever are used due to the high reliability in the system. However, the need for them will probably increase in the future due to more intermittent production, which will give a more complicated operation situation and, therefore, there will be a risk for more outages. The need will probably also increase due to higher demand from electricity access in the society as a whole. Current providers will then not be enough and might not be in the correct location due to other changes in the society and, therefore, there will be an increased need also for new providers of these services in the future.

System stability services can be offered by many providers, but the location in the system is important and control system updates are in most cases needed. The electricity production and consumption of the provider will hardly be affected by provision of the service, which will increase the interest of participation.

Congestion management can be done by all providers; however, it needs to be implemented in different ways depending on the type of provider. By access to the 
service, the utilization rate of the system could go up even if losses increased and there might be limitation to provide renewables into the system on some occasions. Congestions are expected to increase due to the expected new more complicated consumption and production pattern, especially at lower voltage levels where new providers are required due to a lack of existing providers.

PQ services can mainly be provided by converter connected providers (except classical HVDC). Providing the services will increase the need of capacity and will only have limited impact on active power exchange, in an equivalent way as reactive power control. These services could reduce losses in the system and even prevent shorting of the expected lifetime of equipment. Since the number of the components in the system creating PQ issues will increase, there will be an increased need for these kinds of services in the future.

If a provider is investigating the possibility to provide multiple services, the competition between services needs to be studied to assess the risks of not providing the actual service when required.

Depending on the nature of the issues that the service addresses, the physical location of equipment may need to be investigated. For services marked with an (L), the location in the grid is of importance while the other services are system based. It should be noted that the location in the grid may differ from the geographical location. Since grid is often based on different zones, it might be not possible for the provider to offer the service. This problem is most common in services related to distribution systems and especially at low voltage levels, such as voltage control, congestion management and other PQ services as described in Table 2.

An additional application of this categorisation is to identify providers of certain services for a service procurer, either from a system responsibility party, such as TSO or DSO, or from other parties who could benefit from external support, e.g., to fulfil grid codes.

\section{CONCLUSIONS}

Categorisation of ancillary services is proposed to provide an evaluation tool of participation for the present and future actor in the power business. This is made to counteract the ambiguity in the terminology used regarding ancillary services, which might inhibit the development of ancillary services. A common terminology could ease the work by explaining a wider range of providers of ancillary services in order to get higher diversity of providers in the system.

By examination of the categorisation, any need for investments are indicated. The examination is based on the type of provider. In the market, there is also knowledge about competition that is crucial to avoid being ousted. For services that currently have no markets, the categorisation can be used to find suppliers. This could be useful not only for TSOs and DSOs but also for those that have challenges in fulfilling certain grid codes.

The analysis has shown that there will be more opportunities for renewable energy sources and other equipment connected to the electric grid to provide more ancillary services. However, there might be some need for hardware and/or software 
updates. Providing more ancillary services could achieve a decrease in cost and/or negative environmental and social impact of these services and thereby decrease the impact of the power system on the society in the near future.

\section{ACKNOWLEDGEMENTS}

The research has been supported by Smart Grids Plus ERA-Net project CLOUDGRID No.77547 (Transnational CLOUD for Interconnection of Demonstration Facilities for Smart GRID Lab Research \& Development). This project has received funding in the framework of the joint programming initiative ERA-Net Smart Grids Plus, with support from the European Union's Horizon 2020 research and innovation programme.

\section{REFERENCES}

1. Rebours, Y. G., Kirschen, D. S., Trotignon, M., \& Rossignol, S. (2007). A survey of frequency and voltage control ancillary services - Part I: Technical Features. IEEE Transactions on Power Systems, 22(1), 350-357.

2. H. Holttinen, Cutululis, N. A., Gubina, A., Keane, A., \& Van Hulle, F. (2012). Ancillary services: Technical specifications, system needs and costs. Deliverable D 2.2. REserviceS project.

3. ENTSO-E. (2015). Balancing and Ancillary Services Markets. ENTSO-E. [Online]. [Accessed: 10 September 2018] https://docstore.entsoe.eu/about-entso-e/market/ balancing-and-ancillary-services-markets/Pages/default.aspx

4. Federal Energy Regulatory Commission. (2016). Glossary. [Online]. [Accessed: 10 September 2018] https://www.ferc.gov/market-oversight/guide/glossary.asp

5. EURELECTRIC. (2004). Ancillary Services. Unbundling Electricity Products - An Emerging Market. EURELECTRIC Thermal Working Group, Ref: 2003-150-0007.

6. Kroposki, B., Johnson, B., Zhang, Y., Gevorgian, V., Denholm, P., Hodge, B.-M., \& Hannegan, B. (2017). Achieving a 100\% renewable grid: Operating electric power systems with extremely high levels of variable renewable energy. IEEE Power and Energy Magazine, 15(2), 61-73.

7. Alizadeh, M. I., Parsa Moghaddam, M., Amjady, N., Siano, P., \& Sheikh-El-Eslami, M.K. (2016). Flexibility in future power systems with high renewable penetration: A review. Renewable and Sustainable Energy Reviews, 57, 1186- 1193, ISSN 1364-0321.

8. Palizban, O., \& Kauhaniemi, K. (2016). Energy storage systems in modern grids Matrix of technologies and applications. Journal of Energy Storage, 6, 248- 259, ISSN 2352-152X.

9. Jabir, H. J., Teh, J., Ishak, D., \& Abunima, H. (2018). Impacts of demand-side management on electrical power systems: A review. Energies, 11, 1050.

10. Mashhour, E., \& Moghaddas-Tafreshi, S. (2011). Bidding strategy of virtual power plant for participating in energy and spinning reserve markets - Part I: Problem formulation. IEEE Transaction on Power Systems, 26(2), 949-956.

11. Litjens, G.B.M.A, Worrell, E., \& van Sark W.G.J.H.M. (2018). Economic benefits of combining self-consumption enhancement with frequency restoration reserves provision by photovoltaic-battery systems. Applied Energy, 223, 172-187. 
12. Chen, S., Ping, J., Le, X., Yan, Z., Xu, X., Yao, L., \& Xi, J. (2018). Forming bidding curves for a distribution system operator. IEEE Transaction on Power Systems, 33(5).

13. E. Stai, Reyes Chamorro, L. E., Sossan, F., Le Boudec, J.-Y., \& Paolone, M. (2018). Dispatching stochastics heterogeneous resources accounting for grid and battery losses. IEEE Transaction on Smart Grids, 9(6).

14. Nguyen, H., Le, L.B., \& Wang, Z. (2018). A bidding strategy for virtual power plants with the intraday demand response exchange market using stochastic programming. IEEE Transaction on Industrial Applications, 54(4).

15. Nguyen, H. \& Le, L. (2018). Bi-objective-based cost allocation for cooperative demandside resource aggregators. IEEE Transaction on Smart Grids, 9(5).

16. Kundur, P., Balu, N. J., \& Lauby, M. G. (1994). Power system stability and control (Volume 7). New York: McGraw-Hill.

17. ENTSO-E. (2016). Nordic Balancing Philosophy. ENTSO-E.

18. Moreno, O. J. (2017). Ancillary Service for Frequency Support - Design of a Battery Storage Ancillary Service for Frequency Support in the Nordic Power System. Master Thesis, Chalmers University of Technology.

19. ENTSO-E. (2017). NORDIC System Operation Agreement-Appendices. ENTSO-E.

20. Rebours, Y. G., Kirschen, D. S., Trotignon, M., \& Rossignol, S. (2007). A survey of frequency and voltage control ancillary services - Part II: Economic features. IEEE Transactions on power systems, 22(1), 358-366.

21. Svenska Kraftnät AB. (2017). Balance Responsibility Agreement. [Online]. [Accessed: 14 September 2018] https://www.svk.se/en/stakeholder-portal/Electricity-market/ Balance-responsibility/balance-responsibility-agreement/

22. ENTSO-E. (2013). Supporting Document for the Network Code on Load-Frequency Control and Reserves for Electricity, ENTSO-E.

23. European Commission. (2016). Establishing a Guideline on Electricity Transmission System Operation - Draft.

24. Cigré Working Group C5.06, TB 435. (2010). Ancillary Services: An overview of International Practices. Cigré.

25. ERCOT. (2013). Future Ancillary Services in ERCOT - Initial Public Draft Version 1.0. ERCOT.

26. EirGrid., \& Soni. (2012). DS3: System Services Consultation - New Products and Contractual Arrangements.

27. Papalexopoulos, A. D., \& Andrianesis, P. E. (2014). Day ahead energy market and reliability unit commitment: An integrated approach. Power Systems Computation Conference (PSCC), Wroclaw, Poland.

28. Dominguez-Garcia, J. L., Gomis-Bellmunt, O., Bianchi, F. D., \& Sumper, A. (2012). Power oscillation damping supported by wind power: A review. Renewable and Sustainable Energy Reviews, 16(7), 4994-5006.

29. Telaretti, E., \& Dusonchet, L. (2016). Battery storage systems for peak load shaving applications: Part 1: Operating strategy and modification of the power diagram. In IEEE 16th International Conference on Environment and Electrical Engineering (EEEIC) (pp. 1996-2001), 7-10 June 2016, Florence, Italy.

30. Telaretti, E., \& Dusonchet, L. (2016). Battery storage systems for peak load shaving applications: Part 2: Economic feasibility and sensitivity analysis. In IEEE 16th International Conference on Environment and Electrical Engineering (EEEIC) (pp. 2006-2011), 7-10 June 2016, Florence, Italy. 
31. Kim, Y.-J., Blum, D. H., Xu, N., Su, L., \& Norford, L. K. (2016). Technologies and magnitude of ancillary services provided by commercial buildings. Proceedings of the IEEE, 104(4), 758-779.

32. Abinava, M., Senthilnathan, N., \& Sabarimuthu M. (2014). Harmonic compensation as ancillary service in PV inverter based residential distribution system. In International Conference on Circuit, Power and Computing Technologies (ICCPCT), Nagercoil, India.

\title{
SISTĒMAS PALĪGPAKALPOJUMA KLASIFIKĀCIJA PAKALPOJUMA SNIEDZĒJIEM
}

\author{
J. Ehnberg, O. Lennerhag, E. Hillberg, A. Perez,
}

A. Mutule, I. Zikmanis

Kopsavilkums

Elektrisko tîklu attīstība mūsdienās tiecas samazināt ietekmi uz vidi, attīstīt jaunas tehnologijas un inovatīvus risinājumus. Tīkla turpmākā attīstības gaita būtiski ietekmēs tīkla stabilitāti, tādejādi nākotnes tîklā paredzēta paaugstināta nepieciešamība pēc energosistēmas palīgpakalpojumiem.

Šobrīd palīgpakalpojumus var sniegt tikai tīkla dalībnieki, kuri atbilst pārvades tīklu izvirzītajām tehniskajām prasībām. Prasības spēj izpildīt lielie tīkla dalībnieki, toties liels potenciāls atrodams izkliedēto ǵenerācijas avotu un dažādo veidu slodžu lokā. Šis potenciāls netiek pilnvērtīgi izmantots, kas saistīts ar informācijas trūkumu, terminoloǵijas neskaidrībām un nestandarta pieejām. Izmantojot šos mazākos tīkla dalībniekus, ir iespējams sniegt palīgpakalpojumus ar jaunu pieeju.

Raksts klasificē tehniski ekonomisku informāciju par dažādiem sistēmu palīgpakalpojumiem no pakalpojuma sniedzēja puses. Apkopotā informācija sniedz informāciju par pakalpojuma realizācijas sarežǵîtības pakāpi, ieskatu potenciālajā konkurencē, iespēju dažādībā, lokācijas būtībā attiecībā no palīgpakalpojuma, kā arī ieskatu tirgus iespējās.

21.01.2019. 